\title{
Glyphosate-resistant Italian ryegrass and perennial ryegrass in New Zealand - a review
}

\author{
H. Ghanizadeh ${ }^{1}$, K.C. Harrington ${ }^{1}$ and T.K. James ${ }^{2}$ \\ ${ }^{1}$ Institute of Agriculture and Environment, Massey University, PB 11-222, \\ Palmerston North 4442, New Zealand \\ ${ }^{2}$ AgResearch, Ruakura Research Centre, PB 3123, Hamilton 3240, New Zealand \\ Corresponding author: K.Harrington@massey.ac.nz
}

\begin{abstract}
In 2013, three populations of perennial ryegrass (Lolium perenne) and two populations of Italian ryegrass (L. multiflorum) from five vineyards in New Zealand were confirmed to be resistant to glyphosate. The level of resistance in four populations was almost 10 -fold while one population of perennial ryegrass (Population $\mathrm{O}$ ) had a level of resistance greater than 30-fold. Quick tests for confirming the presence of glyphosate in ryegrass plants have been developed. Molecular and physiological investigations showed that there was restricted herbicide translocation in all studied populations and Population $\mathrm{O}$ also had a modification at Pro-106 of the EPSPS enzyme. It was also found that the restricted herbicide translocation can be suppressed under cool conditions. Further studies also showed that the gene causing restricted herbicide translocation could be readily transferred through pollen, and the gene was partially dominant. All glyphosate resistant populations were also resistant to glufosinate, and three of the populations were also resistant to amitrole.
\end{abstract}

Keywords Italian ryegrass, perennial ryegrass, glyphosate resistance, mechanisms of resistance, inheritance, cross-resistance, weed management.

\section{INTRODUCTION}

Glyphosate is a very important herbicide because it can control a wide range of both dicotyledonous and monocotyledonous weeds in agricultural and non-agricultural situations, yet is inactivated on contact with soil (Powles 2008). Glyphosate primarily prevents production of the aromatic amino acids tyrosine, phenylalanine and tryptophan (Herrmann \& Weaver 1999) by inhibiting the enzyme 5-enolpyruvoylshikimate-3-phosphate synthase (EPSPS) within the shikimate pathway (Steinrucken \& Amrhein 1980). The evolution of resistance to glyphosate was thought to be unlikely
(Bradshaw et al. 1997) and no glyphosate-resistant weeds were reported during the first 15 years of glyphosate application (Sammons \& Gaines 2014). However, the first case of glyphosate resistance was found in Lolium rigidum from Australia (Powles et al. 1998) and since then, evolution of resistance to glyphosate has been confirmed in over 30 weed species globally (Heap 2015).

In New Zealand, glyphosate has been used to control weeds in agriculture, vineyards, orchards, roadsides, railways and urban areas for many years (Harrington et al. 2014). In 2013, it was confirmed 
that glyphosate resistance has evolved in Italian ryegrass (Lolium multiflorum) and perennial ryegrass (Lolium perenne) populations from New Zealand vineyards (Ghanizadeh et al. 2013). Since then investigations have been conducted in order to elucidate the mechanism(s) of this glyphosate resistance, the heritability of the resistance and also the pattern of cross-resistance to other herbicides.

The objective of this review is to provide a brief report on the current state of knowledge regarding glyphosate resistance in these ryegrass populations from New Zealand.

\section{RESISTANCE TO GLYPHOSATE IN LOLIUM SPECIES}

The New Zealand glyphosate resistance cases reported in 2013 involved two populations of perennial ryegrass (Populations $J$ and $\mathrm{O}$ ) and two Italian ryegrass populations ( $\mathrm{A}$ and $\mathrm{P}$ ) from four separate Marlborough vineyards, and also a perennial ryegrass population $(\mathrm{N})$ from a Nelson vineyard (Ghanizadeh et al. 2013). Dose response testing showed the level of resistance to glyphosate was similar among four of the populations (A, P, J and $\mathrm{N}$ ) and was approximately 10 -fold. However, one of the perennial ryegrass populations (Population O) showed a level of glyphosate resistance significantly higher than the other populations, and was estimated to be almost 30 times more resistant to glyphosate than a susceptible population (Population SP).

Evolution of glyphosate resistance in both of these ryegrass species has also been reported from overseas (Heap 2015). The spraying history of the vineyards where the five resistant populations were collected showed that glyphosate had been the main herbicide applied at least 2-3 times annually for at least 10 years prior to the resistance being detected. Thus, continual applications of glyphosate has selected for glyphosate-resistant ryegrass. Other cases of resistance may currently be evolving as glyphosate is often used in a similar manner in New Zealand in other vineyards, orchards, road-sides and urban areas.

It was considered important to develop techniques for rapidly detecting resistance to glyphosate to monitor any further resistance. Three tests were developed for detecting glyphosate resistance in ryegrass, namely a seed test, the shikimic assay and the tiller dip assay (Ghanizadeh et al. 2015a). Each test successfully and rapidly discriminated glyphosate-resistant plants from susceptible ones. Results of the tests agreed with the results from sprayed potted plant tests, which is the conventional method for detecting herbicide resistance in weeds. The seed test involved germinating seeds in dilute solutions of glyphosate, whereas the shikimic assay and tiller dip assay could be used to test vegetative plants collected from the field without the need to wait for seed production.

\section{MECHANISMS OF GLYPHOSATE RESISTANCE}

Several different mechanisms of resistance to glyphosate have been reported in other countries, and the level of resistance in weeds depends on the mechanism involved (reviewed by Beckie (2011)). The similar levels of resistance among four of the New Zealand populations suggested a similar mechanism of resistance to glyphosate while the other population $(\mathrm{O})$ was assumed to have evolved a different mechanism of resistance. Both target site and non-target site mechanisms of resistance have been found to confer glyphosate resistance in weeds (Powles \& Yu 2010). Two possible mechanisms of glyphosate resistance were investigated based on previously published work from overseas (Sammons \& Gaines 2014), namely a target site mutation at position Pro-106 of EPSPS and restricted herbicide translocation for both perennial ryegrass (Ghanizadeh et al. 2015b) and Italian ryegrass (Ghanizadeh et al. 2016).

Partial sequencing of the EPSPS genome revealed that of the five populations, only Population $\mathrm{O}$ had the target site mutation at the Pro-106 position. Investigations of restricted herbicide translocation using radiolabelled glyphosate in four populations (Populations A and $\mathrm{P}$ of Italian ryegrass, and Populations $\mathrm{J}$ and $\mathrm{O}$ 
of perennial ryegrass) showed that both resistant and susceptible plants absorbed similar amounts of glyphosate. However, significantly more of the absorbed radiolabelled glyphosate was retained in the treated leaf blade of all glyphosate-resistant ryegrass plants studied compared with susceptible plants, whereas significantly more of the absorbed radiolabelled glyphosate was translocated to the pseudostem region in the susceptible plants. Population $\mathrm{O}$ was shown to have both the target site mechanism of resistance and the restricted herbicide translocation mechanism. Having two mechanisms of glyphosate resistance may explain the higher level of glyphosate resistance within Population O compared to the other glyphosate-resistant populations. Restricted herbicide translocation has been reported as the most common mechanism of resistance to glyphosate (Sammons \& Gaines 2014). Restricted herbicide translocation has been reported in Lolium rigidum (Wakelin et al. 2004), Conyza canadensis (Feng et al. 2004), Lolium multiflorum (Michitte et al. 2007) and Sorghum halepense (Riar et al. 2011).

In glyphosate-resistant Conyza canadensis, the restricted herbicide translocation mechanism of resistance resulted in a massive sequestration of glyphosate within vacuoles shortly after herbicide application in contrast to susceptible plants (Ge et al. 2010). Glyphosate vacuolar sequestration has also been observed for glyphosate-resistant Lolium spp. with the restricted herbicide translocation mechanism of resistance (Ge et al. 2012). Membrane-associated transporters are considered to have a role in shifting glyphosate from the cytoplasm to vacuoles (Yuan et al. 2010; $\mathrm{Ge}$ et al. 2014). Interestingly, Ge et al. (2011) found that vacuolar sequestration of glyphosate is suppressed at cool temperatures. Ghanizadeh et al. (2015c) investigated the effect of temperature on glyphosate resistance in one population of perennial ryegrass (Population J), and found that when treated at a mean temperature of $9^{\circ} \mathrm{C}$, the resistant plants became sensitive to glyphosate applications. Thus glyphosate resistance in Lolium spp. from New Zealand could be due to the vacuolar sequestration of glyphosate.

\section{HERITABILITY OF GLYPHOSATE RESISTANCE TRAIT}

Ghanizadeh (2015) showed that the glyphosate resistance gene in both ryegrass species can be transferred via both pollen and ovules, because the progenies from crossing resistant with susceptible populations were resistant to glyphosate. It was also noted that the glyphosate resistance gene in ryegrass has incomplete dominance because the level of resistance to glyphosate in the reciprocal $\mathrm{F}_{1}$ families was found to be intermediate between original resistant and susceptible populations (Ghanizadeh 2015). The mode of inheritance of glyphosate resistance in a population of Lolium rigidum from Australia with restricted herbicide translocation was also reported to be incompletely dominant (Lorraine-Colwill et al. 2001). This has also been reported for Conyza canadensis in the USA (Zelaya et al. 2004).

\section{THE PATTERN OF RESISTANCE TO OTHER HERBICIDES}

A preliminary experiment was conducted to evaluate resistance to other herbicides used in vineyards, on all five glyphosate-resistant populations of ryegrass (Ghanizadeh 2015). All glyphosate-resistant populations survived the recommended rate of glufosinate and three populations also survived the recommended rate of amitrole. These results indicate possible cross-resistance. Further investigations using two dose-response experiments on one population of Italian ryegrass (Population A) and two populations of perennial ryegrass (Populations J and $\mathrm{O}$ ) confirmed that these glyphosate-resistant populations were also resistant to glufosinate and amitrole (Ghanizadeh et al. 2015d). The mechanisms of amitrole and glufosinate resistance in ryegrass are not currently known, and so any possible links of amitrole and glufosinate resistance to the mechanism of resistance to glyphosate (restricted herbicide translocation) are not understood. Preliminary work has shown that all 
glyphosate resistant populations are still susceptible to ACCase-inhibitor herbicides, especially haloxyfop (Ghanizadeh 2015). Haloxyfop has not yet been registered for use in vineyards in New Zealand, though it would be a useful option for controlling glyphosate-resistant Italian ryegrass and perennial ryegrass in situations other than vineyards where the herbicide is permitted to be applied. Registration for clethodim in vineyards has been sought as this herbicide is also effective.

\section{CONCLUSIONS AND DISCUSSION}

As glyphosate application is the cheapest and most effective way to control weeds in many situations, it would be difficult to convince users of glyphosate to adopt other methods of weed control. However, the evolution of glyphosate-resistant ryegrass is an example of the consequences of over-reliance on glyphosate. Although glyphosate resistance has only been confirmed for two weed species in New Zealand to date, there is a strong likelihood that glyphosate resistance has evolved in other weed species in this country. The likelihood of glyphosate-resistant weeds applies not only to vineyards but also to wherever glyphosate is being used continually.

Restricted herbicide translocation has been found to be the mechanism of glyphosate resistance within all currently-known glyphosate-resistant populations of ryegrass in New Zealand, although one population also had target-site resistance. However, it seems this mechanism of resistance loses its efficacy under cooler (winter) temperatures. A practical option is to spray any glyphosate-resistant ryegrass while temperatures are still cool, as this is when these glyphosate-resistant ryegrasses appear more susceptible to glyphosate. Field trials are required to confirm the susceptibility of these glyphosate-resistant ryegrasses to glyphosate applied during a New Zealand winter.

The gene causing restricted herbicide translocation can be transferred in pollen moving from resistant plants to susceptible ones, although the progenies of pair-crossing between resistant and susceptible plants have intermediate levels of resistance to glyphosate compared with parent plants. Given that both ryegrass species outcross and are wind-pollinated, the glyphosate-resistance gene could spread via pollen from affected vineyards to ryegrass plants on neighbouring properties. However, the seeds produced would have lower levels of glyphosate resistance, and they may never germinate when grown in competitive pastures. Even if they did grow, these glyphosate-resistant plants would only cause a weed problem if they were later sprayed with glyphosate.

All of the glyphosate-resistant Italian ryegrass and perennial ryegrass populations were found to be resistant to glufosinate and some were even resistant to amitrole too. Amitrole has been used extensively in vineyards and orchards in New Zealand since the 1950s (Boyd 1964) so it is possible these populations have evolved resistance to amitrole earlier than when glyphosate resistance was detected. The resistance to glufosinate and amitrole is concerning as they are two important alternative chemicals within vineyards for glyphosate resistance management. The resistance of ryegrass weeds to three common herbicides suggests that weed management will need to include additional methods to control weeds effectively. For example, residual herbicides may need to become more common again in weed management programmes as these will diversify the herbicide modes of action within vineyards, and may be useful for stopping further resistant plants establishing after they have been controlled in late winter.

\section{ACKNOWLEDGEMENTS}

The authors wish to thank the donors of plant material for this study, and the staff of the Plant Growth Unit of Massey University for help growing the ryegrass. They are also grateful for the financial assistance provided by the Massey University Doctoral Scholarship, Seed Tech Services Scholarship, Dan Watkins Scholarship in Weed Science, George Mason Sustainable Land Use Scholarship, Hurley Fraser Postgraduate Scholarship, and the Ministry of Primary Industries through the Sustainable Farming 
Fund and the Foundation for Arable Research.

\section{REFERENCES}

Beckie HJ 2011. Herbicide-resistant weed management: focus on glyphosate. Pest Management Science 67: 1037-1048.

Boyd PG 1964. Field observations with thiocyanate-activated amitrole. Proceedings of the $17^{\text {th }}$ New Zealand Weed and Pest Control Conference: 115-118.

Bradshaw LD, Padgette SR, Kimball SL, Wells BH 1997. Perspectives on glyphosate resistance. Weed Technology 11: 189-198.

Feng PCC, Tran M, Chiu T, Sammons RD, Heck GR, CaJacob CA 2004. Investigations into glyphosate-resistant horseweed (Conyza canadensis): retention, uptake, translocation, and metabolism. Weed Science 52: 498-505.

Ge X, d'Avignon DA, Ackerman JJH, Sammons RD 2010. Rapid vacuolar sequestration: the horseweed glyphosate resistance mechanism. Pest Management Science 66: 345-348.

Ge X, d'Avignon DA, Ackerman JJH, Sammons $\mathrm{RD}$ 2014. In vivo ${ }^{31} \mathrm{P}$-nuclear magnetic resonance studies of glyphosate uptake, vacuolar sequestration, and tonoplast pump activity in glyphosate-resistant horseweed. Plant Physiology 166: 1255-1268.

Ge X, d'Avignon DA, Ackerman JJH, Duncan B, Spaur MB, Sammons RD 2011. Glyphosateresistant horseweed made sensitive to glyphosate: low-temperature suppression of glyphosate vacuolar sequestration revealed by ${ }^{31} \mathrm{P}$ NMR. Pest Management Science 67: 1215-1221.

Ge X, d'Avignon DA, Ackerman JJH, Collavo A, Sattin M, Ostrander EL, Hall EL, Sammons RD, Preston C 2012. Vacuolar glyphosatesequestration correlates with glyphosate resistance in ryegrass (Lolium spp.) from Australia, South America, and Europe: a 31P NMR investigation. Journal of Agricultural and Food Chemistry 60: 1243-1250.

Ghanizadeh H 2015. Aspects of herbicide resistance in three New Zealand weed species. $\mathrm{PhD}$ thesis, Massey University, Palmerston
North, New Zealand. 233 pp.

Ghanizadeh H, Harrington KC, James TK 2015c. Glyphosate-resistant population of Lolium perenne loses resistance at winter temperatures. New Zealand Journal of Agricultural Research 58: 423-431.

Ghanizadeh H, Harrington KC, James TK 2015d. Glyphosate-resistant Lolium multiflorum and Lolium perenne populations from $\mathrm{New}$ Zealand are also resistant to glufosinate and amitrole. Crop Protection 78: 1-4.

Ghanizadeh H, Harrington KC, James TK, Woolley DJ 2013. Confirmation of glyphosate resistance in two species of ryegrass from New Zealand vineyards. New Zealand Plant Protection 66: 89-93.

Ghanizadeh H, Harrington KC, James TK, Woolley DJ 2015a. Quick tests for detecting glyphosate-resistant Italian and perennial ryegrass. New Zealand Journal of Agricultural Research 58: 108-120.

Ghanizadeh H, Harrington KC, James TK, Woolley DJ, Ellison NW 2015b. Mechanisms of glyphosate resistance in two perennial ryegrass (Lolium perenne) populations. Pest Management Science 71: 1617-1622.

Ghanizadeh H, Harrington KC, James TK, Woolley DJ, Ellison NW 2016. Restricted herbicide translocation was found in two glyphosate-resistant Italian ryegrass (Lolium multiflorum) populations from New Zealand. Journal of Agricultural Science and Technology: (in press).

Harrington KC, James TK, Parker MD 2014. Managing glyphosate resistance. http://resistance.nzpps.org/index. php? $\mathrm{p}=$ herbicides/glyphosate (accessed 17 Feb 2016).

Heap I 2015. International survey of herbicide resistant weeds. http://www.weedscience. com (accessed 13 Jan 2015).

Herrmann KM, Weaver LM 1999. The shikimate pathway. Annual Review of Plant Physiology and Plant Molecular Biology 50: 473-503.

Lorraine-Colwill DF, Powles SB, Hawkes TR, Preston C 2001. Inheritance of evolved glyphosate resistance in Lolium rigidum 
(Gaud.). Theoretical and Applied Genetics 102: 545-550.

Michitte P, Prado Rd, Espinoza N, RuizSantaella JP, Gauvrit C 2007. Mechanisms of resistance to glyphosate in a ryegrass (Lolium multiflorum) biotype from Chile. Weed Science 55: 435-440.

Powles SB 2008. Evolved glyphosate-resistant weeds around the world: lessons to be learnt. Pest Management Science 64: 360-365.

Powles SB, Yu Q 2010. Evolution in action: plants resistant to herbicides. Annual Review of Plant Biology 61: 317-347.

Powles SB, Lorraine-Colwill DF, Dellow JJ, Preston C 1998. Evolved resistance to glyphosate in rigid ryegrass (Lolium rigidum) in Australia. Weed Science 46: 604-607.

Riar DS, Norsworthy JK, Johnson DB, Scott RC, Bagavathiannan M 2011. Glyphosate resistance in a Johnsongrass (Sorghum halepense) biotype from Arkansas. Weed Science 59: 299-304.

Sammons RD, Gaines TA 2014. Glyphosate resistance: state of knowledge. Pest Management Science: 1367-1377.
Steinrucken HC, Amrhein N 1980. The herbicide glyphosate is a potent inhibitor of 5-enolpyruvylshikimic acid-3-phosphate synthase. Biochemical and Biophysical Research Communications 94.

Wakelin AM, Lorraine-Colwill DF, Preston C 2004. Glyphosate resistance in four different populations of Lolium rigidum is associated with reduced translocation of glyphosate to meristematic zones. Weed Research 44: 453459.

Yuan JS, Abercrombie LLG, Cao Y, Halfhill MD, Zhou X, Peng Y, Hu J, Rao MR, Heck GR, Larosa TJ, Sammons RD, Wang X, Ranjan P, Johnson DH, Wadl PA, Scheffler BE, Rinehart TA, Trigiano RN, Stewart CN, Jr. 2010. Functional genomics analysis of horseweed (Conyza canadensis) with special reference to the evolution of non-target-site glyphosate resistance. Weed Science 58: 109-117.

Zelaya IA, Owen MDK, VanGessel MJ 2004. Inheritance of evolved glyphosate resistance in Conyza canadensis (L.) Cronq. Theoretical and Applied Genetics 110: 58-70. 